
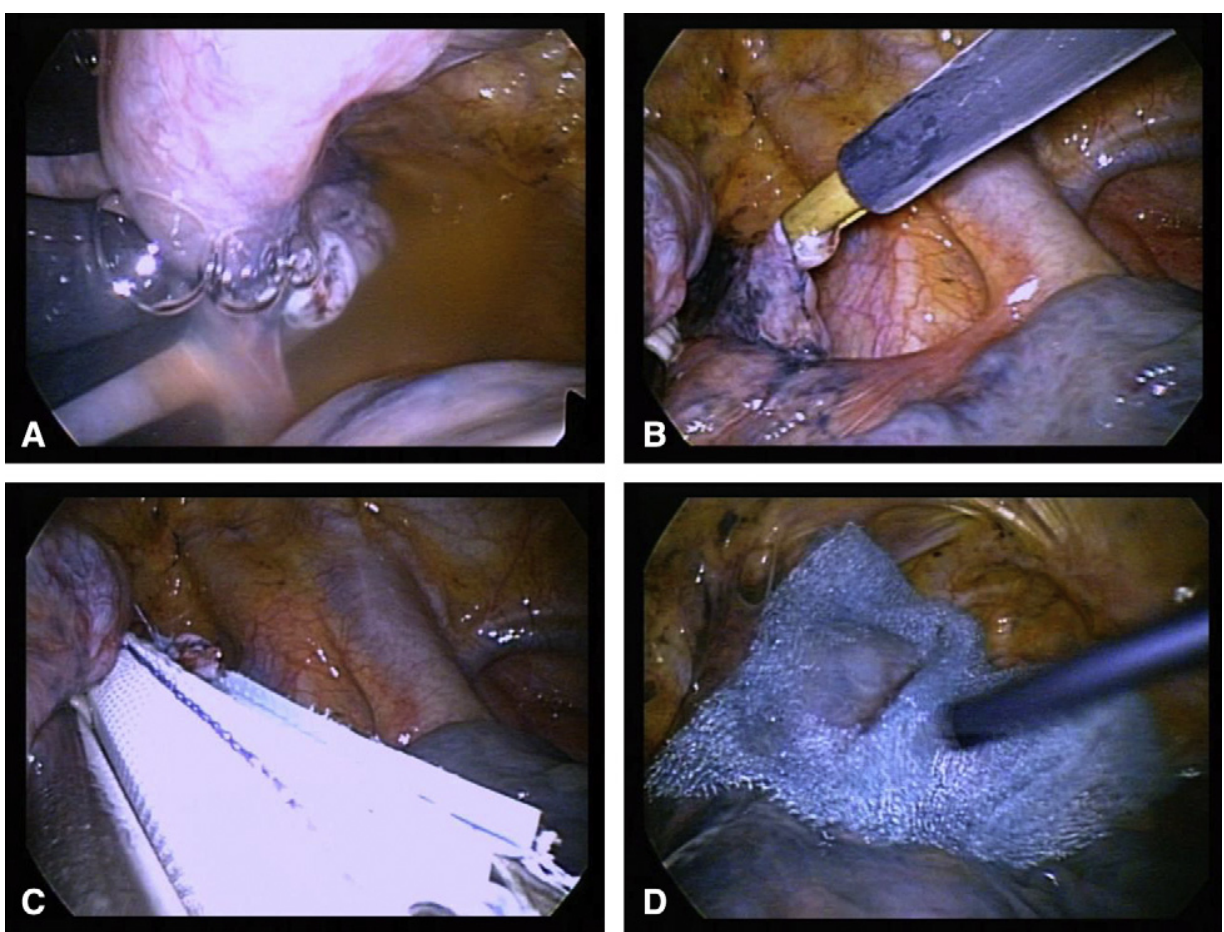

FIGURE 1. Representative repair technique (case 9). A, Specific site of air leakage was identified by lung inflation followed by underwater submersion. B and C, Bulla was resected with an endoscopic linear stapler. D, Lung surface around the suture line was covered with a PGA sheet and fibrin glue.

efficacy of VATS under local and epidural anesthesia to avoid adverse effects with single lung ventilation for intractable pneumothorax in high-risk patients. Despite including patients with a poor clinical condition, these surgical procedures were well tolerated in our series and allowed early resolution of pneumothorax without complications.

\section{CONCLUSIONS}

The minimally invasive surgical approach is an effective option even in elderly patients with intractable secondary pneumothorax.

\section{References}

1. Dillman RO, Zusman DR, McClure SE. Surgical resection and long-term survival for octogenarians who undergo surgery for non-small-cell lung cancer. Clin Lung Cancer. 2009; 10:130-4.

2. Onuki T, Murasugi M, Ikeda K, Oyama K, Nitta S. Thoracoscopic surgery for pneumothorax in older patients. Surg Endosc. 2002;16:355-7.

3. Heffner JE, Huggins JT. Management of secondary spontaneous pneumothorax. Chest. 2004;125:1190-2.

4. Mukaida T, Andou A, Date H, Aoe M, Shimizu N. Thoracoscopic operation for secondary pneumothorax under local and epidural anesthesia in high-risk patients. Ann Thorac Surg. 1998;65:924-6.

5. Shigematsu H, Andou A, Matsuo K, Satoh T, Higashi R. Thoracoscopic surgery using local and epidural anesthesia for intractable pneumothorax after BMT. Bone Marrow Transplant. 2011;46:472-3.

\title{
A simple technique of commissural reconstruction in aortic valve-sparing surgery
}

\author{
Hunaid A. Vohra, MD, MRCS, FRCS (CTh), FETCS, Laurent deKerchove, MD, \\ Jean Rubay, MD, PhD, and Gebrine ElKhoury, MD, Brussels, Belgium
}

\footnotetext{
From the Divisions of Cardiothoracic and Vascular Surgery, Université Catholique de Louvain, Cliniques Universitaires Saint-Luc, Brussels, Belgium.

Disclosures: Authors have nothing to disclose with regard to commercial support.

Received for publication April 28, 2012; revisions received Oct 4, 2012; accepted for publication Nov 6, 2012; available ahead of print Dec 10, 2012.

Address for reprints: Gebrine ElKhoury, MD, Service de Chirurgie Cardiovasculaire et Thoracique, Cliniques Universitaires Saint-Luc UCL, Ave Hippocrate 10, Brussels B-1200, Belgium (E-mail: gebrine.elkhoury@uclouvain.be).

J Thorac Cardiovasc Surg 2013;145:882-6

$0022-5223 / \$ 36.00$

Copyright (c) 2013 by The American Association for Thoracic Surgery http://dx.doi.org/10.1016/j.jtcvs.2012.11.021
}

Techniques of aortic valve repair have proven efficacy; however, these techniques cannot be used to treat all types of valves. In several instances, valve morphology requires commissural reconstruction (CR) with variable cusp extension. Generally, cusp extension techniques are performed with 2 or 3 distinct pericardial patches, which are joined on the aortic root wall to create the neocommissures. ${ }^{1,2}$ We have developed a method of CR with a single pericardial patch, as adapted from a technique described by Tolan and colleagues ${ }^{3}$ in 1997. 

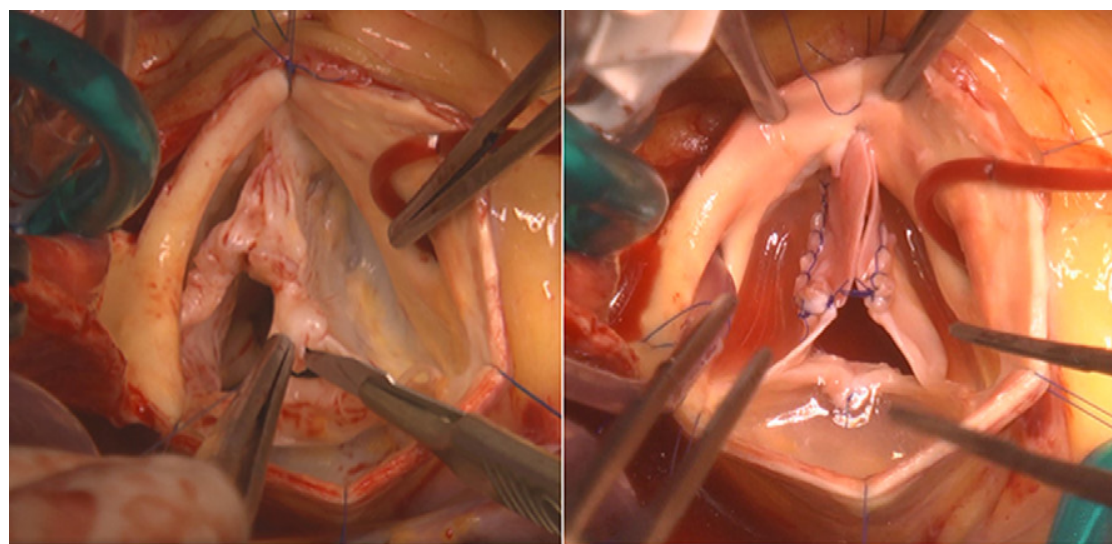

A
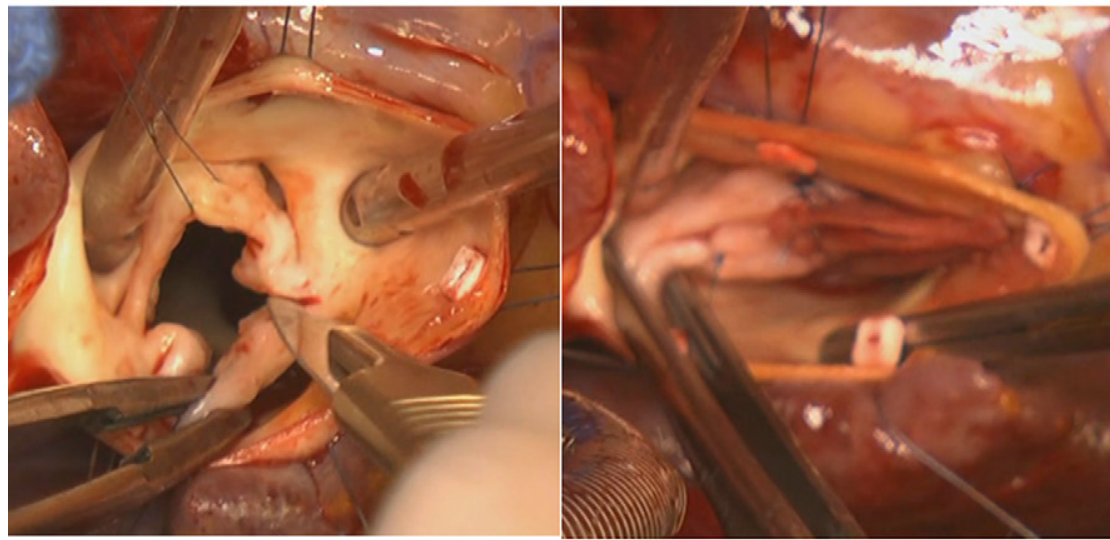

B
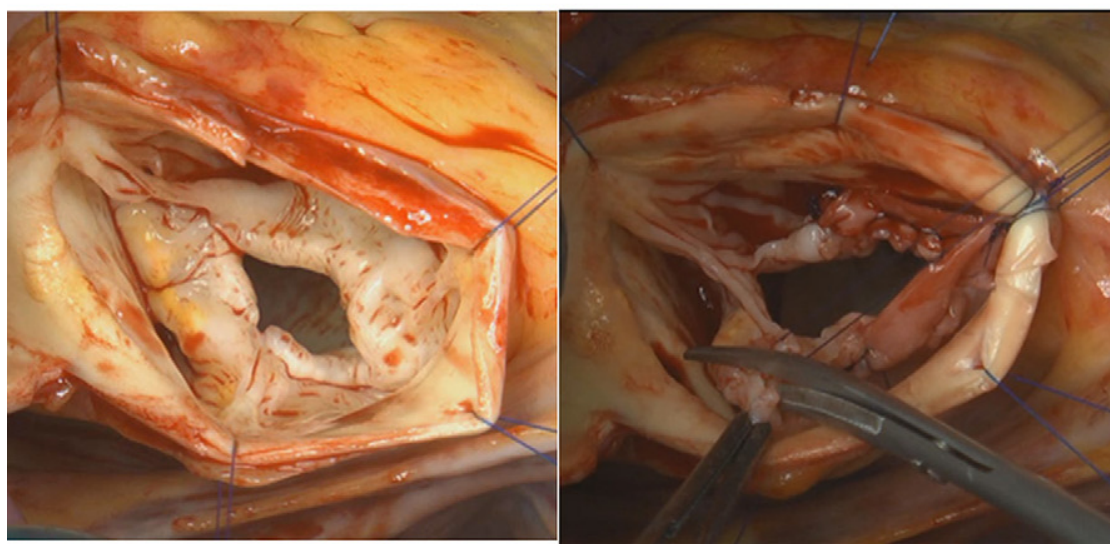

C

FIGURE 1. A, Bicuspid aortic valve type I with restrictive raphe between the right and the left coronary cusps (left) and tricuspidization of the bicuspid aortic valve with the single-patch commissural reconstruction technique (right). A bovine pericardial patch is used to create a new commissure at the place of the raphe. B, In a dysmorphic valve, prolongation after balloon dilatation of the cuspal tear opposite the normal commissure to the aortic annulus (left) and bicuspidization of the dysmorphic valve with the single-patch commissural reconstruction technique (right). A glutaraldehyde-treated autologous pericardial patch is used to create a new commissure at the place of the cuspal tear. C, Unicuspid valve with 2 raphes and 1 normal commissure (left) and bicuspidization of the unicuspid valve with the single-patch commissural reconstruction technique (right). A bovine pericardial patch is used to create a new commissure at the position of the raphe, which is opposite the normal commissure.

\section{MATERIALS AND METHODS}

The single-patch CR technique has been applied in 13 cases since 2007. One indication is the bicuspid aortic valve type 1 with incomplete fusion of the conjoint cusp and restrictive raphe (Figure 1, $A$ and $B$ ). The native valve asymmetry, characterized by a large conjoint cusp and smaller nonconjoint cusp, is favorable for tricuspidization. Our technique creates a new 

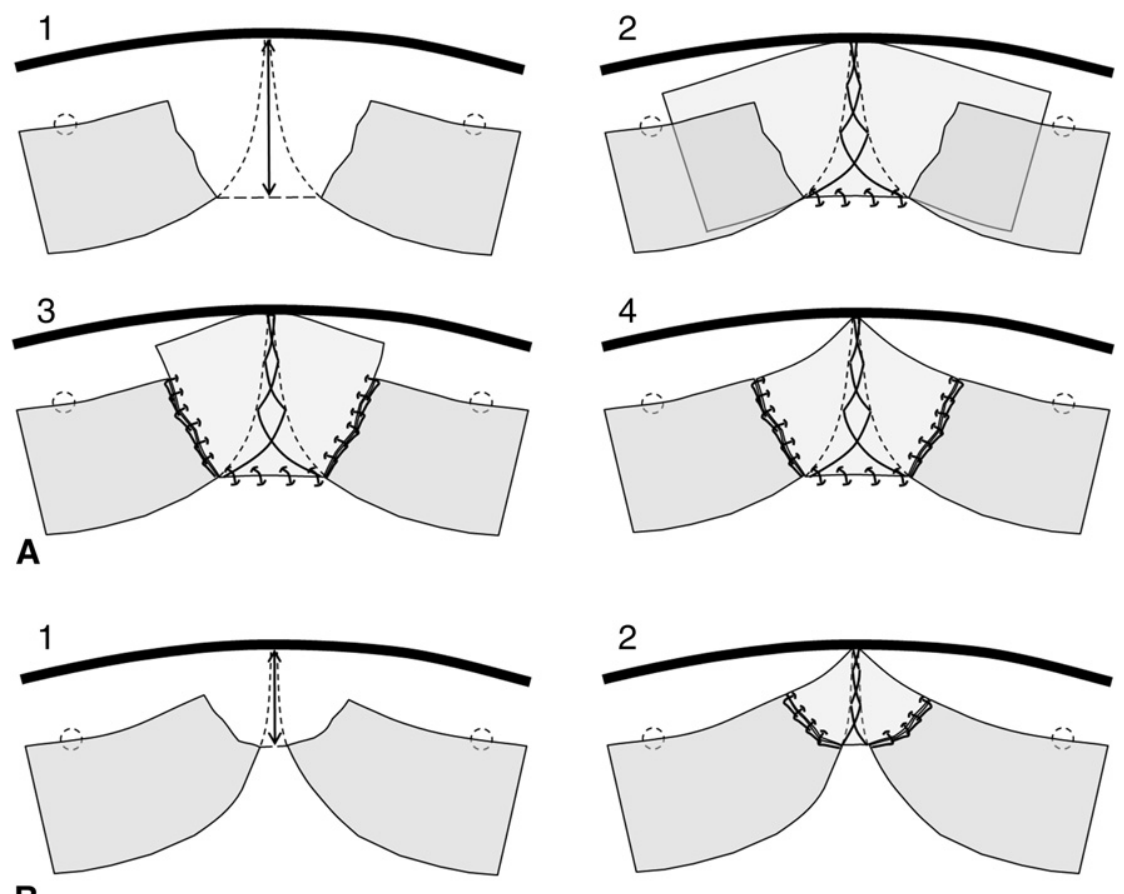

FIGURE 2. Schematic diagram of the single-patch commissural reconstruction technique: A, Large commissural defect. Vertical interrupted lines delineate theoretic cusp insertion and horizontal interrupted line delineate lowest level of cusp resection (1). The double arrow shows the height of the patch needed for commissural reconstruction. Suturing of the patch onto the aortic wall creates a new interleaflet triangle (2). The patch is sutured horizontally along the line joining the limit of cusp resection, then vertically up to the sinotubular junction level. The patch is trimmed laterally to match the line of cusp resection and is sutured to the cusps with a blocked running suture (3). The final result is obtained by trimming the superior border of the patch (4). B, Small commissural defect. Vertical interrupted lines delineate theoretical cusp insertion and horizontal interrupted line delineate the lowest level of cusp resection (1). The double arrow shows the height of the patch needed for commissural reconstruction. The upper part of interleaflet triangle is made only with the vertical suture of the patch onto the aorta; the horizontal suture is not necessary because both cusps are close from each other at this level (2).

commissure at the raphe site. Another indication is the dysmorphic unicuspid aortic valve with a single normal commissure and 0,1 , or 2 rudimentary raphes. Percutaneous balloon dilatation in early life leads to a cuspal tear approximately $180^{\circ}$ from the native commissure, which makes the valve suitable for bicuspidization at the tear site. If percutaneous balloon dilatation is not performed, the neocommissure is created at the raphe site directly opposite the normal commissure. Other indications for CR are tricuspid and bicuspid type 0 aortic valves with commissural calcification, large fenestration, or endocarditis destruction.

Transverse aortotomy is performed, and the aorta is retracted with 4-0 Prolene (Ethicon, Inc, Somerville, NJ). At the neocommissure site, the raphe or the cuspal tear is extended to the aortic wall. The native cusp tissue on each side is preserved to limit the extent of cusp extension. Thickened and fibrotic areas of the cusps are thinned out by sharp dissection. For CR, patch height correspond to the distance between the sinotubular junction to a horizontal line passing through the level of cusp insertion (Figure 2, $A$ and $E$ ). CR is performed with either bovine or treated autologous pericardial patch. The patch is placed horizontally symmetrically across the site of the neocommissure. In the case of a large commissural defect (eg, dysmorphic aortic valve after percutaneous balloon dilatation), the base of the patch is first sutured with continuous 5-0 Prolene to the aortic wall along a horizontal line joining the level of cusp resection (Figure $2, B$ ). Then the patch is sutured vertically onto the aortic wall from its base to the top of the new commissure defined by the sinotubular junction (Figure 2, $B$ ). This is performed with progressively wider stitches from above downward to recreate the interleaflet triangle. ${ }^{4}$ If only the upper half of the commissure needs to be repaired, the first horizontal suture line is not performed, because the cusps are very close to each other in this portion of the interleaflet triangle (Figure 2,E). After the patch has been fixed to the aorta, cusp extension is performed by trimming the patch laterally to match with the cusp resection edge and then attaching the patch with blocked running suture of 6-0 Prolene traveling from cusp insertion to cusp free margin (Figure 2, C). Finally, the upper edge of the patch is trimmed to coincide with the upper curvature of the native cusps (Figure 2, $D$ and $F$ ). The same maneuver is applied to both sides of the neocommissure. Additional procedures are performed according to our general principles of aortic valve repair. ${ }^{5}$ When necessary, free margin plication is performed to equalize adjacent cusp level and optimize coaptation height.

\section{RESULTS}

Preoperative, intraoperative, and postoperative data of the 13 patients are given in Table 1 . Mean age was 31 years, and $92 \%$ of the patients were male. The median clinical follow-up was 11.5 months (range, 0.3-56 months). There were no deaths or valve-related events.

\section{DISCUSSION}

We propose a simple and reproducible method for CR that results in restoration of valve geometry and function and can be applied to unicuspid, bicuspid, and tricuspid aortic valves. This technique aims to restore adequate cusp motion while recreating the interleaflet triangle. The 
TABLE 1. Characteristics of patients who underwent commissural reconstruction

\begin{tabular}{|c|c|c|c|c|c|c|c|c|c|c|}
\hline Case & $\begin{array}{l}\text { Age } \\
(y)\end{array}$ & Sex & $\begin{array}{c}\text { AV } \\
\text { morphology, } \\
\text { commissure } \\
\text { reconstructed } \\
\end{array}$ & $\begin{array}{c}\text { Hemodynamic } \\
\text { abnormality }\end{array}$ & $\begin{array}{l}\text { Etiology and } \\
\text { previous } \\
\text { cardiac } \\
\text { intervention }\end{array}$ & $\begin{array}{c}\text { AV } \\
\text { morphology } \\
\text { after repair } \\
\text { and type } \\
\text { of patch }\end{array}$ & $\begin{array}{l}\text { Associated } \\
\text { procedures }\end{array}$ & $\begin{array}{c}\text { AI by } \\
\text { on-table } \\
\text { TEE }\end{array}$ & $\begin{array}{c}\text { Echocardiographic } \\
\text { FU }\end{array}$ & $\begin{array}{c}\text { Clinical } \\
\text { FU }\end{array}$ \\
\hline 1 & 6 & M & $\mathrm{UC}$, anterior & AI & $\begin{array}{l}\text { Dysmorphic, } \\
\text { PBV, } \\
\text { coarctation } \\
\text { repair }\end{array}$ & $\mathrm{BC}, \mathrm{APP}$ & $\begin{array}{l}\text { Thinning both } \\
\text { cusps, resecting } \\
\text { subaortic } \\
\text { membrane }\end{array}$ & None & $\begin{array}{l}56 \mathrm{mo} \text {, trivial AI, } \\
\text { PG } 6 \mathrm{~mm} \mathrm{MG} \mathrm{NA}\end{array}$ & $\begin{array}{l}56 \text { mo, } \\
\text { no VREs }\end{array}$ \\
\hline 2 & 24 & M & $\mathrm{UC}$, anterior & AI & Dysmorphic & $\mathrm{BC}, \mathrm{APP}$ & $\begin{array}{l}\text { Thinning both } \\
\text { cusps, SCA, } \\
\text { AAR }\end{array}$ & None & $\begin{array}{l}11 \text { mo, mild AI, } \\
\text { PG and MG NA }\end{array}$ & $\begin{array}{l}56 \text { mo, } \\
\text { no VREs }\end{array}$ \\
\hline 3 & 34 & M & $\begin{array}{l}\text { BC type } 0, \\
\text { posterior }\end{array}$ & AI & $\begin{array}{l}\text { Active } \\
\text { endocarditis }\end{array}$ & $\mathrm{BC}, \mathrm{BPP}$ & None & None & $\begin{array}{l}23 \mathrm{mo} \text {, trivial AI, } \\
20 \mathrm{~mm} \mathrm{Hg} \mathrm{PG,} \mathrm{MG} \mathrm{NA}\end{array}$ & $\begin{array}{l}33 \text { mo, } \\
\text { no VREs }\end{array}$ \\
\hline 4 & 9 & M & $\begin{array}{l}\text { BC type } 0, \\
\text { anterior }\end{array}$ & Mixed & $\begin{array}{l}\text { Coarctation and } \\
\text { VSD repair, } \\
\text { AV repair }\end{array}$ & $\mathrm{BC}, \mathrm{BPP}$ & $\begin{array}{l}\text { Thinning LCC, } \\
\text { resection } \\
\text { of subaortic } \\
\text { membrane, } \\
\text { myectomy }\end{array}$ & Trivial & $\begin{array}{l}28 \mathrm{mo} \text {, trivial } \\
\text { AI PG } 30 \mathrm{~mm} \mathrm{Hg} \\
\text { MG } 10 \mathrm{~mm} \mathrm{Hg}\end{array}$ & $\begin{array}{l}33 \text { mo, } \\
\text { no VREs }\end{array}$ \\
\hline 5 & 12 & M & $\mathrm{UC}$, anterior & AS & $\begin{array}{r}\text { Dysmorphic, } \\
\text { PBV }(\times 2)\end{array}$ & $\mathrm{BC}, \mathrm{APP}$ & $\begin{array}{l}\text { Thinning both } \\
\text { cusps, repair } \\
\text { of PAPVD }\end{array}$ & None & $\begin{array}{l}17 \mathrm{mo} \text {, mild } \mathrm{AI}, \\
\text { PG } 75 \mathrm{~mm} \mathrm{Hg}, \\
\mathrm{MG} 40 \mathrm{~mm} \mathrm{Hg}\end{array}$ & $\begin{array}{l}17 \text { mo, } \\
\text { no VREs }\end{array}$ \\
\hline 6 & 44 & M & $\begin{array}{l}\text { BC type } 1, \\
\text { raphe } \\
\text { RCC/LCC }\end{array}$ & AI & Degenerative & TC, BPP & $\begin{array}{l}\text { Plicating NCC, } \\
\text { SCA }\end{array}$ & None & $\begin{array}{l}6 \text { mo, mild AI, } \\
\text { PG } 12 \mathrm{~mm} \mathrm{Hg}, \\
\text { MG NA }\end{array}$ & $\begin{array}{l}11 \text { mo, } \\
\text { no VREs }\end{array}$ \\
\hline 7 & 23 & M & $\mathrm{UC}$, anterior & Mixed & $\begin{array}{c}\text { Degenerative, } \\
\text { PBV }(\times 2)\end{array}$ & $\mathrm{BC}, \mathrm{BPP}$ & $\begin{array}{l}\text { Commissurotomy, } \\
\text { thinning both } \\
\text { cusps, plicating } \\
\text { RCC }\end{array}$ & Mild & $\begin{array}{l}7 \mathrm{mo} \text {, trivial } \mathrm{AI}, \\
\text { PG } 23 \mathrm{~mm} \mathrm{Hg}, \\
\mathrm{MG} 14 \mathrm{~mm} \mathrm{Hg}\end{array}$ & $\begin{array}{l}9 \text { mo, } \\
\text { no VREs }\end{array}$ \\
\hline 8 & 21 & M & $\mathrm{UC}$, anterior & Mixed & Dysmorphic & $\mathrm{BC}, \mathrm{BPP}$ & $\begin{array}{l}\text { Commissurotomy. } \\
\text { thinning both } \\
\text { cusps }\end{array}$ & None & $\begin{array}{l}6 \mathrm{mo} \text {. No AI, } \\
\text { PG } 46 \mathrm{~mm} \mathrm{Hg}, \\
\text { MG } 23 \mathrm{~mm} \mathrm{Hg}\end{array}$ & $\begin{array}{l}9 \text { mo, } \\
\text { no VREs }\end{array}$ \\
\hline 9 & 29 & M & $\begin{array}{l}\text { UC, raphe } \\
\text { RCC/LCC }\end{array}$ & AI & Dysmorphic & $\mathrm{BC}, \mathrm{BPP}$ & $\begin{array}{l}\text { Thinning and } \\
\text { plicating both } \\
\text { cusps, SCA }\end{array}$ & Trivial & $\begin{array}{l}6 \mathrm{mo}, \text { mild AI, } \\
\text { PG } 13 \mathrm{~mm} \mathrm{Hg}, \\
\text { MG } 7 \mathrm{~mm} \mathrm{Hg}\end{array}$ & $\begin{array}{l}13 \text { mo, } \\
\text { no VREs }\end{array}$ \\
\hline 10 & 34 & M & $\begin{array}{l}\text { BC type } 1, \\
\text { raphe } \\
\text { RCC/LCC }\end{array}$ & $\mathrm{AI}$ & Degenerative & $\mathrm{TC}, \mathrm{BPP}$ & $\begin{array}{l}\text { Cusp plication, } \\
\text { valve-sparing } \\
\text { reimplantation }\end{array}$ & None & $\begin{array}{l}5 \mathrm{~d} \text {, trivial AI, } \\
\text { PG } 17 \mathrm{~mm} \mathrm{Hg}, \\
\text { MG } 11 \mathrm{~mm} \mathrm{Hg}\end{array}$ & $\begin{array}{l}4 \text { mo, } \\
\text { no VREs }\end{array}$ \\
\hline 11 & 46 & M & $\mathrm{TC}, \mathrm{NCC} / \mathrm{RCC}$ & AI & $\begin{array}{l}\text { Degenerative, } \\
\text { calcification }\end{array}$ & TC, BPP & $\begin{array}{l}\text { SCA, AAR, } \\
\text { coronary } \\
\text { artery bypass } \\
\text { grafting }(\times 1)\end{array}$ & Trivial & $\begin{array}{l}6 \mathrm{~d} \text {, trivial AI, } \\
\text { PG } 17 \mathrm{~mm} \mathrm{Hg}, \\
\text { MG } 10 \mathrm{~mm} \mathrm{Hg}\end{array}$ & $\begin{array}{l}4 \text { mo, } \\
\text { no VREs }\end{array}$ \\
\hline 12 & 63 & M & $\begin{array}{l}\text { BC type } 1, \\
\text { raphe } \\
\text { RCC/LCC }\end{array}$ & AI & $\begin{array}{l}\text { Degenerative, } \\
\text { calcification }\end{array}$ & TC, BPP & $\begin{array}{l}\text { Thinning both } \\
\text { cusps, plicating } \\
\text { RCC, SCA, } \\
\text { AAR }\end{array}$ & Mild & $\begin{array}{l}4 \mathrm{~d} \text {, mild AI, } \\
\text { PG } 19 \mathrm{~mm} \mathrm{Hg}, \\
10 \mathrm{~mm} \mathrm{Hg}\end{array}$ & $\begin{array}{l}1 \mathrm{mo}, \\
\text { no VREs }\end{array}$ \\
\hline 13 & 55 & $\mathrm{~F}$ & $\mathrm{TC}, \mathrm{LCC} / \mathrm{RCC}$ & AI & $\begin{array}{l}\text { Degenerative, } \\
\text { stress } \\
\text { fenestrations }\end{array}$ & TC, BPP & $\begin{array}{c}\text { Thinning NCC, } \\
\text { SCA, ASD } \\
\text { closure, maze }\end{array}$ & None & $\begin{array}{l}6 \mathrm{~d} \text {, trivial AI, } \\
\text { PG } 17 \mathrm{~mm} \mathrm{Hg}, \\
\text { MG NA }\end{array}$ & $\begin{array}{l}1 \text { mo, } \\
\text { no VREs }\end{array}$ \\
\hline
\end{tabular}

$A A R$, Ascending aorta replacement (supracoronary); $A I$, aortic insufficiency; $A P P$, glutaraldehyde-treated autologous pericardial patch; $A S$, aortic stenosis; $A S D$, atrial septal defect; $A V$, aortic valve; $B C$, bicuspid aortic valve; $B P P$, bovine pericardial patch; $F U$, follow-up; $L C C$, left coronary cusp; $M G$, mean transaortic valve gradient; $N A$, not available; $N C C$, noncoronary cusp; $P A P V D$, partially anomalous pulmonary venous drainage; $P G$, peak transaortic valve gradient; $P B V$, percutaneous balloon valvuloplasty; $R C C$, right coronary cusp; $S C A$, subcommissural annuloplasty; $T C$, tricuspid aortic valve; $T E E$, transesophageal echocardiography; $U C$, unicuspid aortic valve; VRE, valve-related event (includes reoperation, thromboembolism, bleeding, endocarditis); VSD, ventricular septal defect.

aim is to restore coaptation height to midlevel of the sinuses Valsalva and coaptation length to at least $4 \mathrm{~mm}$ and to also restore cusp motion and valve area. ${ }^{5}$ In the older patients,
CR was performed because the disease was localized, and the cusps looked normal after resection. We are confident that a good surgical result can be achieved, and in case of 
future patch calcification the valve function is unlikely to be affected. Moreover, if reoperation is needed, it may be easier. No data exist to show that a bioprosthesis is better than repair for this disease entity in older patients; however, longer follow-up in more patients is necessary to assess the durability of this approach.

\section{References}

1. Polimenakos AC, Sathanandam S, Elzein C, Barth MJ, Higgins RS, Ilbawi MN. Aortic cusp extension valvuloplasty with or without tricuspidization in children and adolescents: long-term results and freedom from aortic valve replacement. J Thorac Cardiovasc Surg. 2010;139:933-41; discussion 941.
2. McMullan DM, Oppido G, Davies B, Kawahira Y, Cochrane AD, d'Udekem d'Acoz Y, et al. Surgical strategy for the bicuspid aortic valve: tricuspidization with cusp extension versus pulmonary autograft. J Thorac Cardiovasc Surg. 2007; $134: 90-8$

3. Tolan MJ, Daubeney PE, Slavik Z, Keeton BR, Salmon AP, Monro JL. Aortic valve repair of congenital stenosis with bovine pericardium. Ann Thorac Surg. 1997;63:465-9.

4. Kunzelman KS, Grande KJ, David TE, Cochran RP, Verrier ED. Aortic root and valve relationships: impact on surgical repair. J Thorac Cardiovasc Surg. 1994; 107:162-70.

5. Boodhwani M, de Kerchove L, Glineur D, Poncelet A, Rubay J, Astarci P, et al. Repair-oriented classification of aortic insufficiency: impact on surgical techniques and clinical outcomes. J Thorac Cardiovasc Surg. 2009;137: 286-94. 